Témoigner Témoigner. Entre histoire et mémoire

Getuigen Revue pluridisciplinaire de la Fondation Auschwitz

$124 \mid 2017$

La musique dans les camps

\title{
De laatste aanval: interview met Jacques Tardi en Dominique Grange
}

\section{Brecht Capiau}

\section{(2) OpenEdition}

1 Journals

Édition électronique

URL : https://journals.openedition.org/temoigner/5697

DOI : 10.4000/temoigner.5697

ISSN : 2506-6390

\section{Éditeur :}

Éditions du Centre d'études et de documentation Mémoire d'Auschwitz, Éditions Kimé

\section{Édition imprimée}

Date de publication : 2 avril 2017

Pagination : 17-20

ISBN : 978-2-930953-00-7

ISSN : 2031-4183

\section{Référence électronique}

Brecht Capiau, «De laatste aanval: interview met Jacques Tardi en Dominique Grange», Témoigner. Entre histoire et mémoire [Online], 124 | 2017, Online op 30 novembre 2021, geraadpleegd op 01 décembre 2021. URL: http://journals.openedition.org/temoigner/5697; DOI: https://doi.org/10.4000/temoigner. 5697

Tous droits réservés 


\section{DE LAATSTE AANVAL: INTERVIEW MET \\ JACQUES TARDI EN \\ DOMINIQUE GRANGE}

STRIP In 2016 publiceerde de Franse striptekenaar Jacques Tardi Le Dernier Assault, in het Nederlands vertaald als De Laatste Aanval. In de strip volgen we Augustin, een eenvoudige brancardier, die ons meeneemt op zijn odyssee doorheen de loopgraven. Het album wordt vergezeld van een cd met protestliederen die zijn geschreven, gecomponeerd en gearrangeerd door Dominique Grange, Tardis echtgenote, en de muzikanten van Accordzéâm. In de kantoren van Casterman in Brussel geeft het koppel tekst en uitleg bij de conceptstrip.

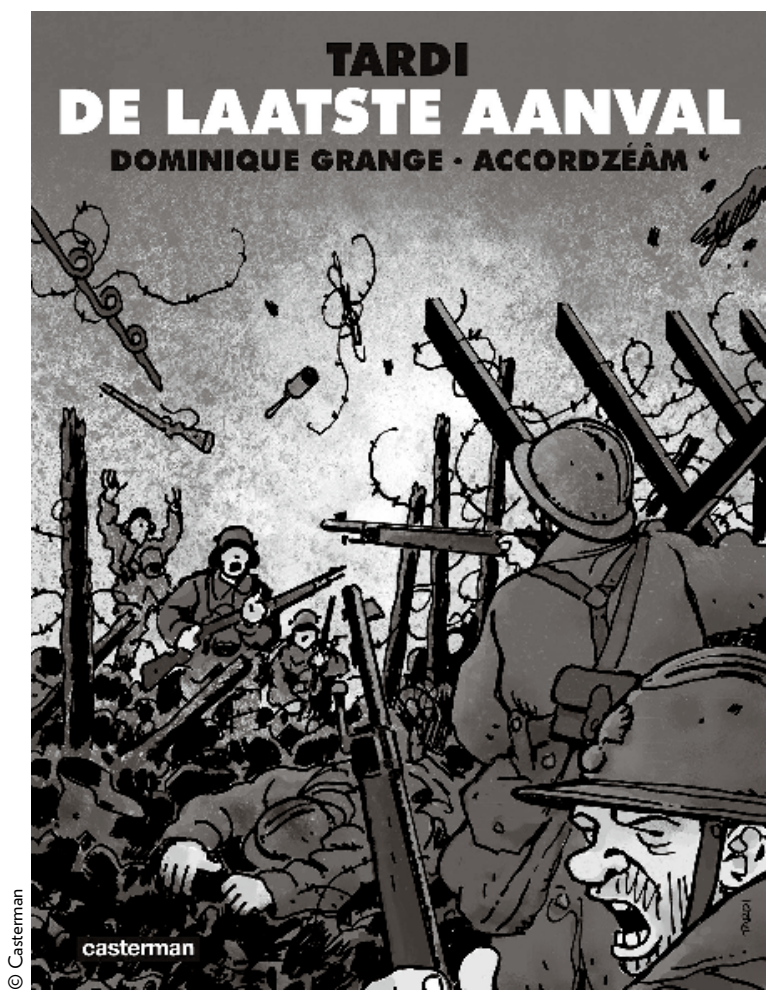

De Laatste Aanval is het laatste luik in een trilogie van stripalbums over de Eerste Wereldoorlog. Was dat steeds het opzet of is dit organisch gegroeid?

Jacques Tardi: Ik had nog veel meer albums over de Eerste Wereldoorlog kunnen maken. Het leven is echter een grillig pad dat je soms naar onvoorziene bestemmingen brengt. Loopgravenoorlog, het eerste album in de trilogie, werd gepubliceerd in het Belgische striptijdschrift $\grave{A}$ Suivre en was vrij episodisch. Het vertelde het verhaal van soldaten, zowel vriend als vijand, aan verschillende fronten en op verschillende tijdstippen. Ik wou geen chronologisch verhaal vertellen, omdat ik vrij soepel met mijn onderwerp wou omgaan. Bij De Grote Slachting koos ik juist wel voor een chronologie. Hierbij was het de bedoeling om de lezer duidelijk te maken dat de Eerste Wereldoorlog liep van 1914 tot en met 1919. In zes hoofdstukken geef ik mijn persoonlijke interpretatie van die oorlogsjaren. Het album eindigt bewust in 1919 omdat ik van mening ben dat de oorlog niet stopte op 11 november 1918. Het is de symbolische datum van de wapenstilstand, maar de oorlog kon in principe op elk moment hervat worden. Het vredesverdrag van Versailles op 28 juni 1919 maakte uiteindelijk een definitief einde •.. 
$\cdots$ aan de wereldbrand. De Laatste Aanval tenslotte beschouw ik als een fictie die sterk doordrongen is van feiten en kennis die ik de voorbije jaren heb opgedaan en die te interessant waren om te laten liggen. Toen ik in de interatig war de in de jaren tachtig begon met mijn onderzoek naar de Eerste Wereldoorlog was er vrij weinig voorhanden. Vandaag zijn er oorlogsdagboeken beschikbaar en zelfs ongecensureerde foto's. Een schat aan infor-

Het stripalbum is vergezeld van een cd met protestHeren. Hoe is het idee ontsoan om muziek en beeld met elkaar te combineren?

Dominique Grange: In 2014 zijn we gestart met dit project. Toen was het opzet vrij eenvoudig. Ik stond op voor Wereldoor Wereldoorlog. Later wam Jacques erbij en hebben we het concept van onze voorstelling artistiek en visuee ditgebreid. Mijn man las tussen de liedjes teksten voo die de themas van de lines jes becommentarieerden, Tijens de voorstelling projecteerden we brachten. nijens de vorstelling projecteerden we beelden die mijn echtgenoot had gemaakt op een groot scherm om onze woorden ook visueel kracht bij te zetten. . op de scène als het resultaat van een versmelting van brach . meer gegroeid uit de voorstellingen.

Brancardier Augustin neemt de lezer mee op een odyssee langs de verschillende loopgraven en ontmoe verhaalvorm gekozen?

JT: Ik vind een brancardier interessant als hoofdpersonage omdat hij altijd als eerste getuige is van de rechtstreekse gevolgen van oorlog. Bovendien is de imptre impact van geweld op de psyche van de mens beter ast te stelch als je cen person meerdere. Dat is ook de reden waarom Augustin vrij is Augustin die darna op orlega is Augustin die daarna op onderzoek gaat, ontdekt, leert, ondervraagt en gedesillusioneerd raakt. De reis or odyssee die onze brancardier onderneemt is deels Augustin in contact te brengen met meniken, pat

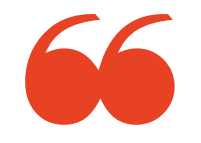

Verontwaardiging was de belangrijikste drijfveer voor het maken van deze conceptstrip. Facques Tardi en Dominique Grange

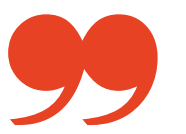

en situaties die mij interesseren. Via mijn hoofdpersonage geef ik bovendien mijn visie en commentaar op de behandeling van de 'zwarte' troepen in het Franse leger, of de inzet van de 'Bantams' in het Britse leger.

Mevrouw Grange, u wees eerder op het sterke verband tussen de strip en de cd. Veel liedjes heeft u zelf geschreven en gecomponeerd. Welke criteria hanteerde u bij de keuze van de andere nummers?

DG: Ik was vooral op zoek naar teksten en liedeen die tegelijkertijd de broederschap tussen de naties ren die tegelijkertijd de broederschap tussen de natie over dit conflict over dit conflict konden vertolken. De Eerste Wereldoorlog was immers voor iedereen, onafhankelijk van nationan we uit bij Bertolt Brecht. Het gedich! Zo Legende vom Toten Soldaten is werkelijk pricht Die De tekst is zo Toed dat we enkel nog de juiste muziek De tekst is zo goed dat we enkel nog de juiste muziek moesten vinden. Verontwaardiging was ook voor on de belangrijkste drijfveer voor het maken van deze onceptstrip.

Het beeld van een kapot geschoten kruisbeeld duikt vaak op in uw striptrilogie over de Eerste Wereldoorlog. Welke rol kan religie spelen in een oorlog? Is het opium voorhervolk, zoals KarlMax or de lijdende soldaat?

$\mathrm{JT}$ : Religie speelde geen enkele rol. De soldaten werden met duizenden tegelijk naar het spreekwoordelijke slachthis geverd. Vroeger vond je langs de wegveel

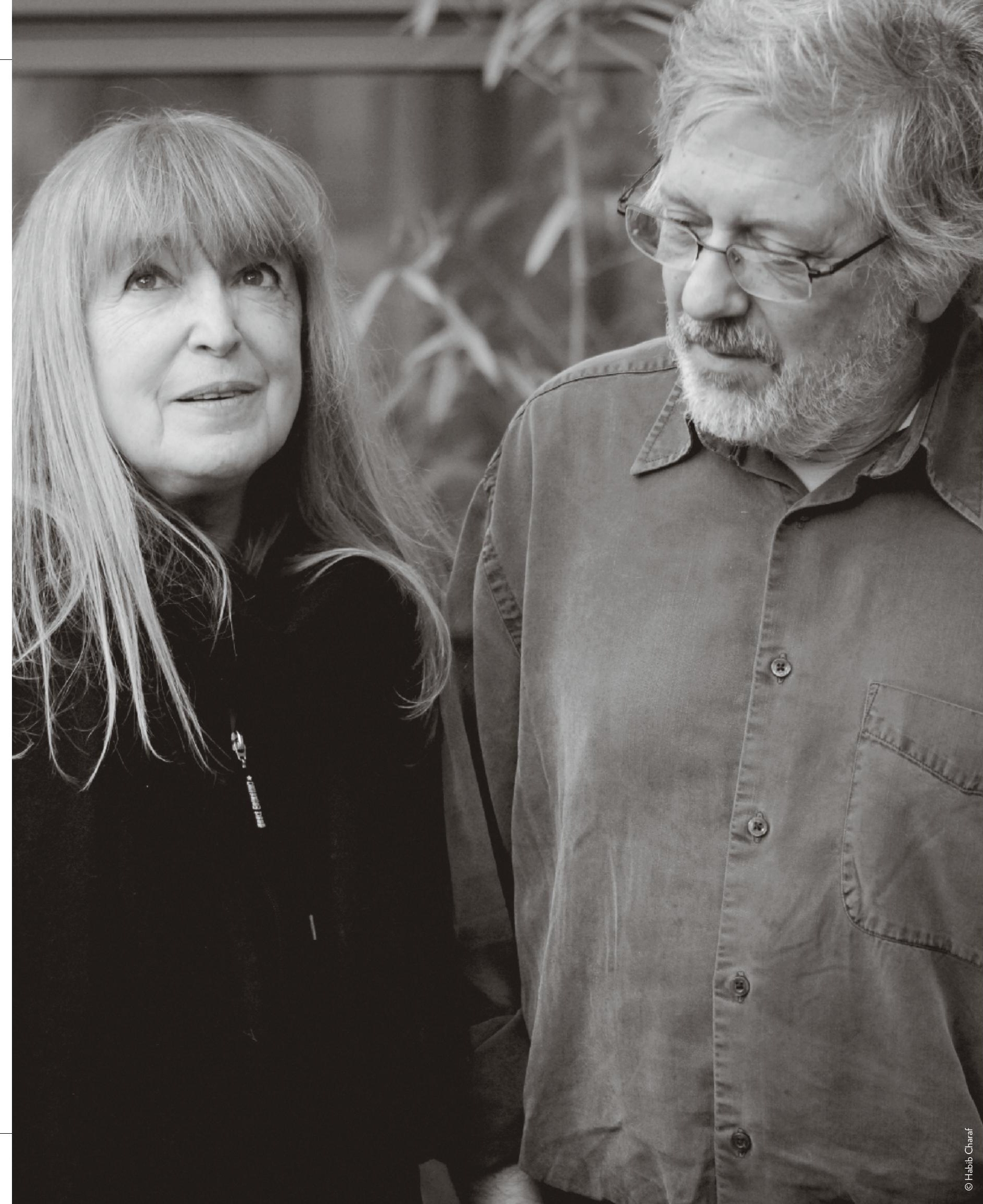


• getoond. Esthetisch vind ik dat wel interessant omdat het zo'n sterk contrast vormt met de realiteit van oorlogsvoering. Met het kapotte kruisbeeld wil ik vooral de absurditeit van religie aantonen. Als je voortdurend beschoten en gebombardeerd wordt, heb je geen tijd om aan 'hogere zaken' te denken. Ik sta volledig buiten het religieuze leven en vind dan ook geen enkele troost of waarde in dat bijgeloof.

Kleur heeft een duidelijke symbolische betekenis in uw werk. Zo is Loopgravenoorlog volledig in zwart-wit uitgebracht. De Grote Slachting begint in kleur en eindigt in zwart-wit. In De Laatste Aanval voeren zwart, grijs en bruin de boventoon. Hoe heeft u het kleurenpalet voor uw striptrilogie samengesteld?

JT: Artistieke, maar helaas ook praktische redenen liggen aan de grondslag van het kleurgebruik. Loopgravenoorlog, mijn eerste album, werd aanvankelijk gepubliceerd in het Belgische striptijdschrift $\grave{A}$ Suivre. De druktechnieken van toen waren echter nog niet zo gesofisticeerd als die van nu. Bovendien was het papier waarop $\grave{A}$ Suivre gedrukt werd van slechte kwaliteit. Als je zwart-wit gebruikt, kan je dat nog deels opvangen. Met het gebruik van zwart-wit wou ik in Loopgravenoorlog vooral het drama van de Eerste Wereldoorlog evoceren. Het idee bij De Grote Slachting was om de folklore van het begin van de oorlog te tonen. Het is zomer en de hemel is blauw. De Franse troepen, gekleed in hun typische blauwe jassen en rode broeken, vertrekken onder luid gejuich en wapperende banieren naar het slagveld. Langzaam maar zeker verdwijnt de kleur uit hun leven als de realiteit zich aandient. De kleuren keren op het einde slechts gedeeltelijk terug omdat er ondanks de overwinning weinig te vieren valt. In $D e$ Laatste Aanval worden de kleuren terug op een klassieke manier gebruikt. Het blijven overwegend donkere kleuren die afhankelijk van de situatie worden ingezet. Het is evident dat je kleur anders inzet bij een gewelddadig beeld vol explosies dan bij een beeld waar er niet zo veel gebeurt.

Ik las onlangs in een interview dat er nog een album volgt van Isabelle Avondrood en nog een van Ik, René Tardi. Daarna is het 'afgelopen' voor u. Blijft u bij dit voornemen?

JT: Het klopt dat ik nog een Isabelle Avondrood wil maken. Tien lijkt me een mooi cijfer om af te ronden. Ik ben sowieso geen voorstander van stripseries die eindeloos doorgaan. In veertig jaar heb ik 'slechts' negen albums van Isabelle Avondrood gemaakt. Voor mij primeert kwaliteit boven kwantiteit. Ik, René Tardi wil ik absoluut afwerken omdat ik meer dan genoeg materiaal heb voor een derde album. In zekere zin gebruik ik die albums om therapeutische redenen. Aangezien ik ben geboren in 1946, kan ik niet fysiek aanwezig zijn tijdens de gebeurtenissen in de strips. Vandaar dat ik in het eerste album een jongetje introduceer, mijn ongeboren ik, dat dialogeert met zijn vader. Via die 'spookfiguur' ben ik in staat om allerlei zaken te bespreken met mijn vader die ik tijdens zijn leven jammer genoeg niet heb kunnen aanhoren.

De volgende anekdote over mijn vader wil ikje tenslotte niet onthouden. Na de oorlog keerde hij samen met de bezettingstroepen terug naar Duitsland. Daar aangekomen kocht hij een auto: een Volkswagen nog wel, de auto die de nazi's indertijd promootten voor de gewone man! Zonder enige kritische reflectie koos uitgerekend hij, die krijgsgevangene was geweest, voor zo'n auto. Het is een mooie illustratie van de volharding van de mens om verder te willen gaan met het leven en niet stil te staan bij de horror van vroeger. Mijn vaders oorlog was uitgewoed.

Brecht Capiau

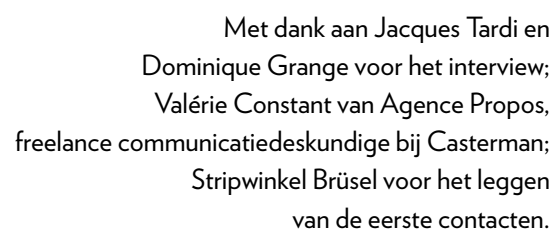

van de eerste contacten. $\rightarrow$ Meer zoeten
$\rightarrow$ In de rubriek 'Boekenplank' leest u een recensie van het
album De Laatste Aanval.

\section{Bibliografie}

Jacques Tardi en Dominique Grange, Le Dernier Assaut, Casterman, 2016. Stripverhaal en cd in samenwerking met Accordzéâm.

Jacques Tardi en Dominique Grange, De Laatste Aanval, Studio Peter de Raaf, België, Casterman, 2016. 